Nigerian Journal of Environmental Sciences and Technology (NIJEST)

www.nijest.com

ISSN (Print): 2734-259X ｜ＩSSN (electronic): 2734-2603

Vol 5, No. 1 March 2021, pp 110 - 119

\title{
Impact of Seasonal Variations on the Colonial Populations of Bacteria and Fungi in Soil and on Buried Plant Stems
}

\author{
Nwokoro O. ${ }^{1}$ and Ekwem O. H. ${ }^{2}$ * \\ ${ }^{1}$ Department of Microbiology, University of Nigeria, Nsukka, Nigeria \\ ${ }^{2}$ South East Zonal Biotechnology Centre, University of Nigeria, Nsukka, Nigeria \\ Corresponding Author: ogechi.ekwem@unn.edu.ng
}

https://doi.org/10.36263/nijest.2021.01.0242

\begin{abstract}
Forest soils and stems buried in them usually have varying degrees of colonization and abundance of bacteria and fungi. This study was undertaken to determine the effects of seasonal variations on the population of bacteria and fungi isolated from forest soil and on plant stems buried in the soil. Soil sampling and stem burial studies were conducted over a 12-month period in 2019. Serially diluted soil samples were plated on suitable media for bacterial and fungal growth and thereafter counted after incubation. Buried stems were removed from the soil, rinsed and placed in flasks containing suitable media for fungal and bacterial cultivation. Colonial growth was counted after incubation. Soil moisture was highest during the wet season months of July (27.7\%), August (23.5 $\%)$, September $26.1 \%)$ and October (29\%) whereas the average soil moisture content was lowest in the dry season. Seasonal pH did not significantly affect microbial population levels in the various months. Colony counts for Pseudomonas spp. during the dry season months (January, February, March and April) were very low. Growth of the bacterium showed peaks in the May through October during which counts reached $10^{9}$ cells per gram of soil except in August with counts of $10^{8}$ cells per gram of soil. Micrococcus spp. and Bacillus spp. also showed similar trends in colony counts with little variations. Fungi were generally fewer in number than bacteria and only one peak which reached $10^{7}$ cells $/ g$ soil was obtained for Fusarium spp. and Rhizopus spp. in September and October respectively. The density of Trichoderma spp. per gram of soil peaked at $10^{6}$ cells in June, July, September and October. Counts for Aspergillus spp. was negligible in January, February, March and April but reached $10^{6}$ cells per gram of soil in June, July and August. The colonization of Pseudomonas spp. on buried plant stem varied between $62 \%$ in June to $76 \%$ in October while Micrococcus spp. had levels which varied from $65 \%$ in May to $84 \%$ in June and $72 \%$ in October. Fusarium species were found most frequently on the stem every month except in February, March and April. Low colonization of Aspergillus spp. on stems occurred in January, February, March, November and December. Highest numbers of this organism was found in August, September and October. Rhizopus spp. was observed in 85 and $80 \%$ of the stem in September and October respectively but lower percentages of colonization occurred in January, February, March and April. In all the dry season months (January-April), all bacterial and fungal populations had low densities but their counts increased in the rainy season. Fungi were generally fewer in number than bacteria in both soil and stem burial experiments.
\end{abstract}

Keywords: Microbial population, Soil sampling, Stem burial, Forest soil, Colonization rate

\subsection{Introduction}

Forest represents one of the largest and most important ecosystems on earth covering more than 40 million $\mathrm{km}^{2}$ representing $30 \%$ of the global land and forest ecosystems are found in most of earth's biomes and harbour a large population of global diversity (Liado et al., 2007). Soil microorganisms constitute nearly $1 \%$ of the soil mass and they have a major impact on soil properties and processes (Cenciani et al., 2009). Nutrient cycles and functioning of the ecosystem are influenced by seasonal changes of soil microbial biomass (Lipson and Schmidt, 2004). Many biological activities which influence the growth of plants, animals and microbial populations occur in the soil. Microorganisms found in forest soil have been shown to perform various beneficial roles such as decomposition of soil 
organic matter, nitrogen cycling and increase of soil fertility (Symochko et al., 2015). The activities and numbers of soil microorganisms determine soil fertility and its environmental status in the ecosystems as reflected on the level of soil biological activities (Cenciani et al., 2009). Microbial diversity in the forest soil occupying a particular location within the soil or on forest ground have been discovered to be affected by various environmental and climatic conditions. The soil microbial inhabitants could be referred to as the dominant organisms in contrast to transient organisms which do not occur most frequently throughout the months. The determination of the impact of environmental change on soil microbial function requires an understanding of how environmental factors shape microbial community and composition in the soil.

Determinations of numbers of microorganisms in soil as well as their isolations, morphological and physiological characteristics are important because soil is a huge reservoir of many biologically active agents. An active microorganism is capable of colonizing and growing on substrates and should be present in large numbers as to alter its environment. The existence of microorganisms in a particular environment including humid or warm environment usually develops through the ability of that organism to grow and multiply on the nutrients available in that locality or which have been transmitted to that locality.

Forest soil clearly represents the most important habitat for soil microorganisms especially fungi and bacteria with their activities being supported by the decomposition of organic matter, dead plant and animal remains. Microorganisms are responsible for the decomposition of soil organic matter thereby releasing nutrients that are absorbed by plants. These microorganisms are of importance in maintaining the fertility of the soil and factors which alter the rate of microbial processes in the soil are of importance for the functioning of the forest ecosystem. Although fungi are known to be the most dominant in forest soil but some bacteria are also abundant in most forest soils and results from recent studies have demonstrated an active role of bacteria in litter transformation (Liado et al., 2007).

Temperature of the tropical forest soil is always warm and moisture is abundant in the wet season and the relative humidity is high. Plants occasionally shed their leaves and provide organic matter on which microorganisms grow on and derive their energy. The spatial heterogeneity of forest top soils determines the composition of microbial communities mainly through two sets of drivers which include soil and litter chemistry which affect both bacteria and fungal population and diversities, although to variable degrees (Baldrian, 2017). Leaves of living plants provide shade for protection of microorganisms from direct sunlight. This makes biological activity intense and results in the abundance of different microbial forms in the forest soil. Dead plant biomass including fallen leaves and deadwood are the sources of most carbon compounds for forest microorganisms. Tons of fallen leaf matter which accumulate yearly on forest floor surface and their transformations is of great importance for the cycling of carbon and other nutrients. Litter habitat is composed of a diverse group of fungi and bacteria which play important roles in decomposition and transformation of forest soil organic matter.

Woody biomass of trees is a large resource in forest ecosystem which is reach in nutrients. Many and diverse species of microorganisms are well adapted to living on woods (Blanchette and Shaw, 1978). Fungi and bacteria are important in the soil ecosystem because they function in the decomposition mineralization and help in the movement of soil mineral elements to plant roots (Widawati and Suliash 2001). Species of fungi are important components of biodiversity in tropical forest soils and fungi perform some activities on which larger organisms including humans depend. Reported values of soil fungal diversity and population are a reflection of the sampling methods which differ from one organism to the other (Brock, 1987). Saprotrophic basidiophytes and white-rot wood-decomposing fungi often act as major litter decomposers together with ascomycetous fungi (Eichlerova et al., 2015). Deadwoods are also a source of carbon compounds in the forest. Decomposition of dead woods is influenced by diversities and types of fungi and bacterial species and also on the environmental conditions prevalent in that habitat (Gessner, 2010). Microorganisms produce a wide range of extracellular enzymes, which allows them to effectively degrade recalcitrant fractions of dead plant biomass (Eichlerova et al., 2015). Bacterial strains are among the dominant group of organisms in the forest soil. The ability of bacteria to survive ecological conditions includes the formation of endospores which have thick strong walls which make it easy for them to survive in extremes of environmental conditions (Kundu et al., 2009). Forests provide a wide range of habitats 
for bacteria and they are abundant on forest soils and litter. Forest ecosystem provides a broad range of habitats for bacteria, including soil and plant roots but bacteria seems to be especially abundant on the forest floor, in soil and litter. Soil bacteria are the primary drivers of these ecological habitats (Bardgett and Leemas 1995). Currently, bacteria community composition is an important determinant of ecosystem process rates, and identifying bacteria community composition has become an essential component for predicting ecosystem responses to environmental changes (Baldrian et al., 2012). However, before we can predict the ecosystem response to environmental change, we must first understand how the environment shapes bacteria community composition. For example, soil moisture can influence bacterial composition along topographic gradients as well as in multiple forest ecosystems (Brockett et al., 2012).

Forests represent a highly productive ecosystem that act as carbon sinks where soil organic matter is formed from residues after biomass decomposition as well as from rhizodeposited carbon (Baldrian, 2017). And factors such as $\mathrm{pH}$, organic matter content, nutrient availability, climate conditions and biotic interactions affect the composition of bacterial communities in the soil is one of the important components and microbial activities and diversities in the soil help drive ecological and physicochemical reactions that occur in soil microenvironment. The determination of the impact of environmental change on soil microbial function requires an understanding of how environmental factors shape microbial composition (Allison et al., 2010). Microbial community composition is an important determinant of ecosystem process rates (Reed and Martiny 2007), and identifying microbial community composition has become an essential component for predicting ecosystem responses to environmental change (Baldrian, et al., 2012). Climatic change alters the relative abundance and function of soil communities because soil community members differ in their physiology, temperature sensitivity, and growth rates (Castro et al., 2010; Gray et al., 2011). The direct effects of climatic change on microbial composition and activities have been well studied (Castro et al., 2010).

Soil temperature is an important physical property that regulates most of the physical, chemical, and biological processes of the soil, and the physiological processes of soil organisms and forest plants (Zogg et al., 1997). Soil temperature has tremendous ecological impacts through evaporation, transpiration, organic matter decomposition, $\mathrm{CO}_{2}$ emission due to soil respiration. In forest ecosystems, soil temperature regulates microbial transformations of nitrogen sulphur and other nutrients and controls decomposition of organic matter and formation of humus. Temperature is one of the most important factors influencing soil organic matter decomposition and microbial communities. Temperature, together with moisture content is among the most important environmental factors affecting microbial growth and activity in soils. The role of elevated temperature on microbial metabolism has received considerable recent attention (Bradford et al., 2008; Karhu, 2014).

Soil moisture is one the most important environmental factors influencing soil organic matter decomposition and production of greenhouse gases in terrestrial environments (Kirschboum, 2006). Soil water content is important in regulating oxygen diffusion, with maximum aerobic microbial activity occurring at moisture levels between $50 \%$ and $70 \%$ of water-holding capacity (WHC) (Linn and Doran, 1984). Seasonal changes in soil water content influence functionstructure relationships of microbial communities and enzyme activities (Brockett et al., 2012). Soil moisture content, by altering conditions for soil microbiota, causes changes in the structural diversity and activity of microorganisms (Kim et al., 2008). Excess of water in the soil environment due to flooding or periodically heavy rainfalls is particularly threatening to aerobic bacteria (Walker et al., 2003). For soil microbiologist, it is important to determine the optimum moisture content of soil because it is the soil microbiota that is responsible for the rate of organic matter transformations in the soil microenvironment.

Soil $\mathrm{pH}$ is considered as one of the important factors that controls microbial community structure (Fierer and Jackson 2006; Lauber et al., 2009). pH influences abiotic factors, such as carbon availability, nutrient availability, and the solubility of metals etc. (Cho et al., 2016). In addition, soil $\mathrm{pH}$ also controls biotic factors, such as the biomass composition of microorganisms in both forest and agricultural soils (Rousk et al., 2010). This work is aimed to study the effects of seasonal variations on bacterial and fungal populations in forest soils and how these variations affect the colonization of buried plant stems over a 12-month examination period. 


\subsection{Materials and Methods}

\subsection{Study area and sampling}

The topography of the study area is characterized by mean maximum and minimum temperatures which lie between $30-3^{\circ} \mathrm{C}$ and $20-25^{\circ} \mathrm{C}$ respectively. Rainy season in the area lasts for about 8 months from April to early November, with peaks in July, September and October. The dry season commences from mid-November to March. Soil samples were collected from $1-5 \mathrm{~cm}$ of top soil and after passing the sample through sieve clothe, soil moisture was determined by placing soil in aluminium foil and the weights of the samples were measured. The soil was oven dried at $105^{\circ} \mathrm{C}$ for $24 \mathrm{~h}$ to achieve a constant weight. Soil moisture was determined gravimetrically by weight deference and the values were converted to percentages.

Soil pHs were determined twice a month by placing $20 \mathrm{~g}$ of air dried soil in glass beaker. Distilled water was added into the beaker and shaken. Soil $\mathrm{pH}$ was then determined with hand held $\mathrm{pH}$ meter (Hannah instrument).

\subsection{Isolation and culturing}

The experimental plot located in a forest in Uzo-Uwani, Nsukka measured $10 \mathrm{x} 5 \mathrm{~m}$ and was mapped with wire gauze to avoid disturbance. Soil samples were collected twice per month from January to December 2019 from the surface $(0-5 \mathrm{~cm})$. The samples were gently collected into sterile conical flasks containing either Nutrient broth for bacterial cultivation or Potato Dextrose broth and shaken at $50 \mathrm{x} \mathrm{g}$ in Gallenkamp shaker for $5 \mathrm{~h}$. The samples were serially diluted using normal saline solution and plated onto Nutrient agar for bacterial enumeration and Potato Dextrose agar (PDA) plates for the enumeration of fungi. Control uninoculated plates were separately prepared. Nutrient agar plates were incubated at $35^{\circ} \mathrm{C}$ in an incubator for $24 \mathrm{~h}$. The PDA plates were placed on the laboratory bench for 48 $\mathrm{h}$ at an approximate temperature of $30 \pm 2^{\circ} \mathrm{C}$. Colony counts were obtained from the plates after the incubation periods. Pure bacterial cultures were obtained by streaking on fresh agar plates. Only plates containing 30 and less than 300 colonies were considered valid. Otherwise, they were not recorded (NR).

\subsection{Stem burial studies}

Sterile banana stems each measuring $10 \times 3 \mathrm{~cm}$ were placed inside the soil at a depth of about $12 \mathrm{~cm}$. Eight such stems were buried on the first day of every month. Soil was added to completely burn the stems. Two buried stems were each removed for either bacterial or fungal examination after 14th and 28th day of burial. Each stem was aseptically rinsed in sterile distilled water and placed in conical flasks containing Nutrient broth for bacterial cultivation or Potato Dextrose broth for fungal cultivation; then shaken at $50 \mathrm{x}$ g in Gallenkamp shaker for $5 \mathrm{~h}$. The samples were serially diluted using normal saline solution and plated onto Nutrient agar for bacterial enumeration and Potato Dextrose agar (PDA) plates for the enumeration of fungi. Nutrient agar plates were incubated at $35^{\circ} \mathrm{C}$ in an incubator for $24 \mathrm{~h}$. The PDA plates were placed on the laboratory bench for $48 \mathrm{~h}$ at an approximate temperature of $30 \pm 2^{\circ} \mathrm{C}$. Pure bacterial cultures were obtained by streaking on fresh agar plates. Only plates containing 30 and less than 300 colonies were considered valid. Otherwise, they were not recorded (NR).

\subsection{Identification of the isolates}

Bacteria were identified based on their morphological, physiological and biochemical characteristics as described in Bergey's Manual of Determinative Bacteriology (Holt et al., 1994). Fungal isolates were identified based on their morphological and cultural characteristics as outlined by Pitt and Hocking (1997).

\subsection{Results and Discussions}

Bacteria and fungi showed differences in their rates of occurrence in both the soil experiment and the stem burial studies. Four bacterial genera namely, Bacillus spp., Pseudomonas spp. and Micrococcus spp. were recovered from the soil in high numbers and they also showed best stem colonization. 
Fungal strains namely Aspergillus spp., Fusarium spp, Rhizopus spp., and Trichoderma spp. were dominant in the soil samples and were isolated in high numbers but only three of these fungi namely Aspergillus spp., Fusarium spp, and Rhizopus spp. displayed best colonization of the buried plant stems.

Results in Figure 1 show the mean soil moisture contents of the study area. It is evident that soil moisture was highest during the wet season months of July, (27.7\%); August, (23.5\%); September, $26.1 \%$ and October $(29 \%)$ whereas the average soil moisture contents were lowest in January, (6.4\%); February, (5.6\%); March, (3.1\%); April, (17.6\%). Data in Figure 2 shows the average soil $\mathrm{pH}$ values for the various months and these changes did not give any significantly positive growth responses to microbial population levels.

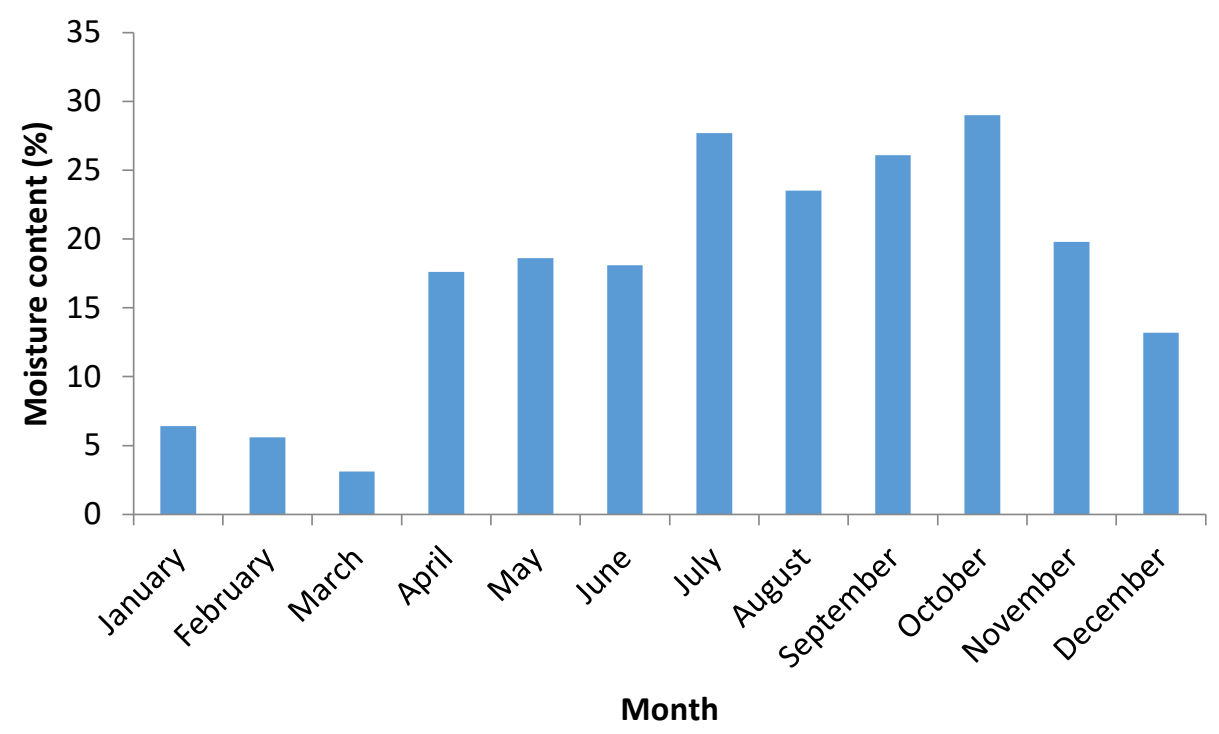

Figure 1: Moisture contents of soil at the study location

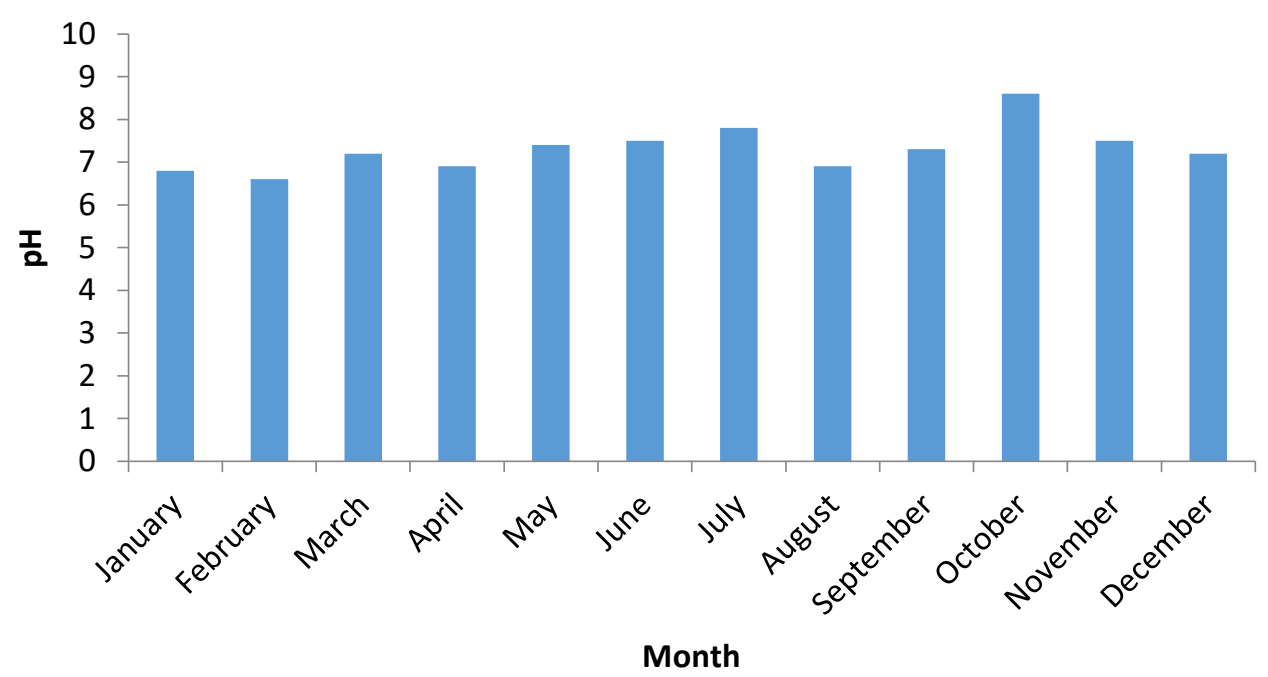

Figure 2: Soil $\mathrm{pH}$ at the study location

For Pseudomonas spp., colony counts during the dry season months (January, February, March and April) were very low (Table 1). Colonial growth showed peaks in May, June, July, September and October during which counts reached $10^{9}$ cells per gram of soil. This level fell in November and December. Bacillus spp. and Micrococcus spp. counts also showed similar trends with little variations (Table 1). In all the dry season months (January-April), all bacterial populations did not reach densities of $10^{6}$ cells/gram of soil (Table 1). 
Table 1: Relative frequency of bacteria per gram forest soil measured over a 12-month period

\begin{tabular}{|l|l|l|l|}
\hline \multirow{2}{*}{ Month } & \multicolumn{3}{|c|}{ Number of organisms } \\
\cline { 2 - 4 } & Pseudomonas spp. & \multicolumn{2}{|c|}{ Bacillus spp. } \\
\hline January & NR & NR & NR \\
\hline February & NR & $2.6 \times 10^{2}$ & NR \\
\hline March & $6.3 \times 10^{2}$ & $3.1 \times 10^{2}$ & NR \\
\hline April & $6.5 \times 10^{3}$ & $3.4 \times 10^{3}$ & $3.2 \times 10^{3}$ \\
\hline May & $8.2 \times 10^{9}$ & $6.2 \times 10^{8}$ & $4.9 \times 10^{4}$ \\
\hline June & $7.4 \times 10^{9}$ & $6.5 \times 10^{9}$ & $6.9 \times 10^{8}$ \\
\hline July & $7.9 \times 10^{9}$ & $7.3 \times 10^{9}$ & $8.8 \times 10^{8}$ \\
\hline August & $8.1 \times 10^{8}$ & $8.1 \times 10^{9}$ & $7.4 \times 10^{9}$ \\
\hline September & $7.8 \times 10^{9}$ & $7.4 \times 10^{9}$ & $7.9 \times 10^{9}$ \\
\hline October & $6.5 \times 10^{9}$ & $8.6 \times 10^{8}$ & $4.9 \times 10^{9}$ \\
\hline November & $5.1 \times 10^{8}$ & $5.4 \times 10^{7}$ & $8.2 \times 10^{7}$ \\
\hline December & $4.8 \times 10^{3}$ & $5.2 \times 10^{5}$ & $2.1 \times 10^{2}$ \\
\hline
\end{tabular}

NR: Not recorded

During the months of January, February, March, April and December 2019, there was very little rainfall and the numbers of fungi were very low (Table 2). Fungi were fewer in number than bacteria and only one peak which reached $10^{7}$ cells/g soil was obtained for Fusarium spp. in September and for Rhizopus spp. in October. The density of Trichoderma spp. per gram of soil started to increase from April and peaked at $10^{6}$ cells in June, July, September and October. Colony counts for Aspergillus spp. was negligible in January, February, March and April but reached $10^{6}$ cells per gram of soil in June, July and August. Colony counts of Aspergillus spp. reduced in September and October with further reductions in November and December (Table 2).

Table 2: Relative frequency of fungi per gram forest soil measured over a 12-month period

\begin{tabular}{|c|c|c|c|c|}
\hline \multirow{2}{*}{ Month } & \multirow[b]{2}{*}{ Aspergillus spp. } & \multicolumn{3}{|c|}{ Number of organisms } \\
\hline & & Fusarium spp. & Rhizopus spp. & Trichoderma spp. \\
\hline January & $6.2 \times 10^{2}$ & $2.8 \times 10^{3}$ & NR & NR \\
\hline February & $2.8 \times 10^{2}$ & NR & NR & NR \\
\hline March & NR & $\mathrm{NR}$ & NR & NR \\
\hline April & $1.0 \times 10^{4}$ & $4.0 \times 10^{3}$ & $3.9 \times 10^{3}$ & $5.1 \times 10^{5}$ \\
\hline May & $2.1 \times 10^{5}$ & $6.4 \times 10^{5}$ & $3.6 \times 10^{5}$ & $1.6 \times 10^{5}$ \\
\hline June & $6.5 \times 10^{6}$ & $5.5 \times 10^{5}$ & $4.4 \times 10^{7}$ & $3.9 \times 10^{6}$ \\
\hline July & $5.3 \times 10^{6}$ & $4.9 \times 10^{6}$ & $5.9 \times 10^{7}$ & $4.1 \times 10^{6}$ \\
\hline August & $4.9 \times 10^{6}$ & $4.2 \times 10^{6}$ & $5.8 \times 10^{6}$ & $4.0 \times 10^{5}$ \\
\hline September & $6.9 \times 10^{5}$ & $4.1 \times 10^{7}$ & $4.2 \times 10^{6}$ & $6.6 \times 10^{6}$ \\
\hline October & $9.2 \times 10^{5}$ & $8.5 \times 10^{6}$ & $2.6 \times 10^{7}$ & $7.5 \times 10^{6}$ \\
\hline November & $9.5 \times 10^{3}$ & $7.4 \times 10^{5}$ & $7.5 \times 10^{5}$ & $4.9 \times 10^{5}$ \\
\hline December & $6.6 \times 10^{2}$ & $3.8 \times 10^{4}$ & $4.3 \times 10^{5}$ & $\mathrm{NC}$ \\
\hline
\end{tabular}

NR: Not recorded

A number of previous studies have explored the influence of multiple environmental factors on the distribution of soil moisture (Nyberg, 1996; Crave and Gascuel-Odoux, 1997). Marked seasonal changes in vegetative cover were also thought partially to explain differences in soil moisture variability observed on different sampling dates (Reynolds, 1970). Reynolds (1970) examined the relationship between soil moisture variability, amount of rainfall and insolation received in the week preceding the sampling, and the moisture content and vegetation cover at the time of sampling. Although no attempt was made to infer the relative influence of each of these factors, trends were identified that were consistent with the notion that soil moisture variability increases with increasing mean moisture content. Specifically, it was noted that low variance was associated with dry periods i.e. low mean moisture content; and that high variance was associated with wet periods.

Bacteria grew in small colonies from the stems with percent colonization higher than the fungi (Table 3 ). The highest colonization for all three bacteria occurred between the months of May through October. The occurrence of Pseudomonas varied between $62 \%$ in June to $76 \%$ in October while Micrococcus spp. had levels which varied from $65 \%$ in May to $84 \%$ in June and $72 \%$ in October. Bacillus spp. had highest colonization rates in May with percent colonization at $61 \%$. Highest reductions in the percent colonization of stems for all three bacteria occurred in the dry season months such that in January, February and March almost all the stems had very low percent colonization rates (Table 3). 
Table 3: Colonization of buried stem by bacteria measured over a 12-month period

\begin{tabular}{|l|l|l|l|}
\hline \multirow{2}{*}{ Month } & \multicolumn{3}{|c|}{ Percent colonization } \\
\cline { 2 - 4 } & Pseudomonas spp. & \multicolumn{1}{|c|}{ Bacillus spp. } & Micrococcus spp. \\
\hline January & NR & 30 & NR \\
\hline February & NR & NR & NR \\
\hline March & NR & NR & NR \\
\hline April & 40 & 45 & NR \\
\hline May & 50 & 61 & 65 \\
\hline June & 62 & 49 & 80 \\
\hline July & 77 & 36 & 84 \\
\hline August & 72 & 40 & 79 \\
\hline September & 79 & 46 & 80 \\
\hline October & 76 & 48 & 72 \\
\hline November & 49 & 45 & 39 \\
\hline December & 35 & 31 & 31 \\
\hline
\end{tabular}

NR: Not recorded

The numbers of fungi were examined as they grew and colonized the buried sterile banana stems. Colony totals of fungi which grew from the buried stems are summarized in Table 4. Only three fungal species namely Aspergillus, Fusarium, Rhizopus were predominant during the stem burial studies. The stem burial experiment showed a similar pattern as the soil experiment for instance, during the dry season months, there were generally low microbial counts as compared to counts obtained in wet season months (Table 4). Fusarium species were found most frequently on the stem every month except in February, March and April. Representative members of this genus appeared most frequently and more consistently than the other fungi especially from May to November and its occurrence varied between 75\% in June and July; 81\% in August and 73 and 79\% in September and October respectively. Variations were found in January, February, March and April. Suppression of Aspergillus spp. occurred in January, February, March, November and December. Highest numbers of this organism was found in August, September and October. Rhizopus spp. was observed in 85 and $80 \%$ of the stem in September and October respectively but lower percentages of colonization was recorded in January, February, March and April. All fungi were more prevalent in August, September and October and decreased in January, February, March, April and December. Changes in soil nutrient content and some other environmental conditions more especially the availability of rainfall must have played a role in the pattern of microbial composition in soil and stem as reported in this work.

Table 4: Colonization of buried stem by fungi measured over a 12-month period

\begin{tabular}{|l|l|l|l|}
\hline \multirow{2}{*}{ Month } & \multicolumn{3}{|c|}{ Percent colonization } \\
\cline { 2 - 4 } & Aspergillus spp. & \multicolumn{1}{|c|}{ Fusarium spp. } & Rhizopus spp. \\
\hline January & 30 & 32 & NR \\
\hline February & NR & NR & NR \\
\hline March & NR & NR & NR \\
\hline April & 44 & NR & NR \\
\hline May & 69 & 64 & 62 \\
\hline June & 52 & 75 & 71 \\
\hline July & 50 & 75 & 69 \\
\hline August & 62 & 81 & 77 \\
\hline September & 68 & 73 & 85 \\
\hline October & 72 & 79 & 80 \\
\hline November & 38 & 53 & 60 \\
\hline December & 32 & 39 & 53 \\
\hline
\end{tabular}

NR: Not recorded

Numbers of both fungi and bacteria varied from time to time and from month to month. This tends to confirm that some elements of the microenvironment influence the types and numbers of microorganisms in the forest soil microenvironment (Girvan, 2003). It was reported that species of microorganisms must reach at least $10^{6}$ cells /g of soil to be of ecological importance in the soil (Symochko et al., 2015), but findings from this work revealed that for both soil experiment and stem burial studies, this level was not attained in the dry season months. The soil $\mathrm{pH}$ did not significantly influence microbial population levels as reported in this work. Cho et al. (2016) stated that soil pH was critical to microbial community diversities and growth and these responses differed between a naturally acidic conifer forest soil with low $\mathrm{pH}$ and a sub urban forest soil with neutral $\mathrm{pH}$ but was 
loaded with several contaminants. Soil characteristics such as moisture, composition and diversity of substrates positively affected microbial population in the soil (Loeppmann et al., 2016). In the forest environment, large amounts of litter fall in the dry season and microorganisms derive energy by the metabolism of these organic matters, but this increased addition of organic matter did not result to increased fungal and bacterial densities observed in this study. Highest reductions in percent microbial colonization of the stem occurred in dry season months especially in January, February, March and April contrary to high percent colonization observed in the rainy season. It is evident from this work that soil water content optimally determined microbial population and Zogg et al. (1997) suggested that free water connecting soil particles optimally influenced microbial population and diversity patterns by controlling nutrient availability and cell movement while Brockett et al. (2012) reported that soil moisture was the major factor that influenced microbial community structure and enzyme activities across seven biogeoclimatic zones in western Canada.

\subsection{Conclusions}

This investigation was conducted to observe the populations of bacteria and fungi in forest soil determined over a 12-month period. Microbial colonization of buried straw was also evaluated with a view to finding how seasonal variations affect the rates of plant stem colonization by the organisms. Different levels of growth responses in terms of bacterial and fungal populations occurred due to changes in some environmental conditions like moisture and $\mathrm{pH}$. Microbial population was highest during the wet season and the lowest fungal and bacterial populations occurred in the dry season. Positive growth responses of the organisms were largely dependent on the soil moisture but did not significantly depend on soil $\mathrm{pH}$.

\section{References}

Allison, S. D., Wallenstein, M. D. and Bradford, M. A. (2010). Soil-carbon response to warming dependent on microbial physiology. Nature Geoscience, 3, pp. 336-340.

Baldrian, P., Kolarik, M., Stursova, M., Kopecky, J., Valaskova, V., Vetrovsky, et al. (2012). Active and total microbial communities in forest soil are largely different and highly stratified during decomposition. The ISME Journal, 6, pp. 248-258.

Baldrian, P. (2017). Forest microbiome: diversity complexity and dynamics. FEMS Microbiology Review, 41, pp. 109-130.

Bardgett, R. D. and Leemas, D. K. (1995). The short-term effects of cessation of fertilizer applications, limiting and grazing on microbial biomass and activity in a reseeded upland grassland soil. Biology and Fertility of Soils, 19, pp. $148-154$.

Blanchette, R. and Shaw, C. (1978). Associations among bacteria, yeasts and basidiomycetes during wood decay. Phytopathology, 63, pp.1-7.

Bradford, M. A., Davies, C. A., Frey, S. D., Maddox, T. R., Melillo, J. M., Mohan, J. E., et al. (2008). Thermal adaptation of soil microbial respiration to elevated temperature. Ecology Letters, 11, pp. 1316-1327.

Brock, T. D. (1987). The study of microorganisms in situ: Progress and Problems. Symposium of the Society of General Microbiology, 41, pp. 1 - 17.

Brockett, B. F. T., Prescott, C. E. and Grayston, S. J. (2012). Soil moisture is the major factor influencing microbial community structure and enzyme activities across seven biogeoclimatic zones in western Canada. Soil Biology and Biochemistry, 44, pp. 9-20.

Castro, H. F., Classen, A. T., Austin, E. E., Norby, R. J. and Schadt, C. W. (2010). Soil microbial community responses to multiple experimental climate change drivers. Applied and Environmental Microbiology, 76, pp. 999-1007. 
Cenciani, K., Lambias, M. R., Cerri, C. C., Basilio den Azevedo, L. C. and Feigl, B. J. (2009). Bactria diversity and microbial biomass in forest, pasture and fallow soils in the Southwestern Amazon basin. Revista Brasileira de Ciencia do Solo, 33, pp. 907- 916.

Cho, S., Kim, M. and Lee, Y. (2016). Effect of pH on soil bacterial diversity. Journal of Ecology and Environment, 40, pp. 10

Crave, A. and Gascuel-Odoux, C. (1997). The influence of topography on time and space distribution of soil surface water content. Hydrological Processes, 11, pp. 203-210.

Eichlerova, I., Homolka, L., Zifcakova, L., Lisa, L., Dobiasova, P., and Baldrain, P. (2015). Enzymatic systems involved in decomposition reflects the ecology and taxonomy of saprotrophic fungi. Fungal Ecoogy, 13, pp. $10-22$.

Fierer, N. and Jackson, R. B. (2006). The diversity and biogeography of soil bacterial communities. Proceediings of the National Academy of Sciences, 103, pp. 626-63.

Gessner, M. O. (2010). Diversity meets decomposition. Trends in Ecological Evolution, 25, pp. 372380 .

Girvan, M. S., Bullimore, J., Pretty, J. N., Osborn, A. M. and Ball, A. S. (2003). Soil type is the primary determinant of the composition of the total and active bacterial communities in arable soils. Applied Environmental Microbiology, 69, pp. 1800-1809.

Gray, S. B., Classen, A. T., Kardol, P., Yermakov, Z. and Miller, R. M. (2011). Multiple climate change factors interact to alter soil microbial community structure in an old-field ecosystem. Soil Science Society of America Journal, 75, pp. 2217-2226.

Holt, J. G., Krieg, N. R., Sneath, P. H. A., Staley, J. T. and Williams, S. T. (1994). Bergey's Manual of Determinative Bacteriology. 9th Ed. Baltimore, USA: Williams and Wilkins.

Karhu, K. (2014). Temperature sensitivity of soil respiration rates enhanced by microbial community response. Nature, 513, pp. 81-84.

Kim S.-Y., Lee S.-H., Freeman C., Fenner, N. and Kang, H. (2008). Comparative analysis of soil microbial communities and their responses to the short-term drought in bog, fen, and riparian wetlands. Soil Biology and Biochemistry, 40, pp. 2874-2880.

Kirschboum, M.U. (2006). The temperature dependence of organic-matter decomposition - still a topic of debate. Soil Biology and Biochemistry, 38, pp. 2510-2518.

Kundu, B. S., Nehra, K., Yadav, R. and Tomar, M. (2009). Biodiversity of phosphate solubilizing bacteria in rhizosphere of chickpea mustard and wheat grown in different regions of Haryana. Industrial Journal of Microbiology, 49, pp. 120 - 127.

Lauber, C. L., Hamady, M., Knight, R., and Fierer, N. (2009). Pyroseguencing- based assessment of soil $\mathrm{pH}$ as a predictor of soil bacterial community structure at the continental scale. Applied and Environmental Microbiology, 75, pp. 5111-5120.

Liado, S., Lopez - Mondejar, R. and Baldrian, P. (2017). Forest soil bacteria: Diversity, involvement in Ecosystem processes and response to global change. Microbial Molecular Biology Review, 81(2).

Linn, D. M. and Doran, J. W. (1984). Effect of water filled pore space on carbon dioxide and nitrous oxide production in tilled and non-tilled soils. Soil Science Society American Journal, 48, pp. 12671272 .

Lipson, D. A. and Schmidt, S. K. (2004). Seasonal changes in an Alpine soil bacterial community in the Colorado Rocky Mountains. Applied and Environmental Microbiology, 70, pp. 2867 - 2879. 
Loeppmann, S., Blagodatskaya, E., Pausch, J. and Kuzyakov, Y. (2016). Substrate quality affects kinetics and catalytic efficiency of exo-enzymes in rhizosphere and detritusphere. Soil Biology and Biochemistry, 92, pp. 111-118.

Nyberg, L. (1996). Spatial variability of water content in the covered catchment at Gardsjon, Sweden, Hydrological Processes, 10, pp. 89-103.

Pitt, J. and Hocking, A. D. (1997). Fungi and food spoilage. London, United Kingdom: Blackie Academic and Professional.

Reynolds, S. G. (1970). The gravimetric method of soil moisture determination, III: An examination of factors influencing soil moisture variability. Journal of Hydrology, 11, pp. 288-300.

Rousk, J., Baath, E., Brookes, P. C., Lauber, C. L., Lozupone, C., Caporaso, J. G. et al. (2010). Soil bacterial and fungal communities across a $\mathrm{pH}$ gradient in an arable soil. The ISME Journal, 4, pp $1340-1351$.

Symochko, L., Patyka, V., Symochko, V. and Kalinichenko, A. (2015). Soil microbial activity and functional diversity in Primeval Beech forests. Journal of Earth Science and Engineering, 5, pp. 363371.

Widawati, S. and Suliasih (2001). The population of nitrogen fixing bacteria and phosphate solubilizing bacteria in the rhizosphere from Gunung Halimum National Park, Edisi Khusus Biodiversittas Taman National Gunung Halimum. Berita Biologi, 5, pp. 691 - 695.

Walker, T. S., Bais, H. P., Grotewold, E. and Vivanco, J. M. (2003). Root exudation and rhizosphere biology. Plant Physiology, 132, pp. 44-51.

Zogg, G. P., Zak, D. R., Ringelberg, D. B., MacDonald, N.W., Pregitzer, K. S. and White, D. C. (1997). Compositional and functional shifts in microbial communities due to soil warming. Soil Science Society of America Journal, 61, pp. 475-481.

\section{Cite this article as:}

Nwokoro O. and Ekwem O. H. 2021. Impact of Seasonal Variations on the Colonial Populations of Bacteria and Fungi in Soil and on Buried Plant Stems. Nigerian Journal of Environmental Sciences and Technology, 5(1), pp. 110-119. https://doi.org/10.36263/nijest.2021.01.0242 